\title{
ANALISIS PENGGUNAAN TWIN BLOCK PADA PERAWATAN MALOKLUSI DENTOSKELETAL KELAS II DIVISI 1 DISERTAI RETROGNATI MANDIBULA BERDASARKAN CERVICAL VERTEBRAL MATURATION STAGE
}

Deta Putri Futuhat ${ }^{*}$, Arlette Suzie P ${ }^{* *}$, Meirina Gartika ${ }^{* *}$

\begin{tabular}{|c|}
\hline Keywords: \\
Class II division \\
1 dentoskeletal \\
malocclusion with \\
mandibular retrognatic, \\
twin block, mandibular \\
dimension, anterior \\
facial height, cervical \\
vertebral maturation \\
stage (CVMS) \\
\hline
\end{tabular}

\begin{abstract}
Background: Class II division 1 dentoskeletal malocclusion with mandibular retrognatic can be treated with twin block appliance. The objectives of this study are to analyse twin block appliance based on mandibular dimension and anterior facial height changes, and to determined the most effective time base on CVMS to begin the treatment.

Method: The type of research was a retrospective analysis study using secondary data. The sample was 14 lateral cephalometric radiographs before and after treatment with twin block appliance. It was taken in IKGA RSGM FKG UNPAD 2010 to 2016. Statistic analysis used paired t-test.

Results: Study shows that there is a significant change $(p<0.05)$ in mandibular dimension and anterior facial height after treatment with twin block appliance. Changes in mandibular dimension including total mandibular length, mandibular body length, ramus height, and gonial angle. Changes in anterior facial height including lower anterior facial height and total anterior facial height. The CVMS III group showed statistically significant result with the biggest improvement.

Conclusion: The use of twin block appliance in Class II division 1 dentoskeletal malocclusion with mandibular retrognatic could change mandibular dimension and anterior facial height. Apart from that, CVMS III was found to be the most effective time to start the treatment with twin block appliance
\end{abstract}

\section{PENDAHULUAN}

Keberhasilan perawatan pasien yang dirawat secara ortodonti dan ortopedi salah satunya ditentukan oleh waktu perawatan yang tepat. ${ }^{1,2}$ Perawatan yang dimulai pada tahap maturasi yang optimal akan memberikan hasil yang terbaik. ${ }^{2}$ Perawatan dengan intervensi ortodonti hanya dapat memodifikasi pola pertumbuhan, bukan menghasilkan pertumbuhan. Penentuan waktu perawatan ortopedi dentofasial yang optimal sangat berkaitan dengan identifikasi waktu percepatan pertumbuhan, sehingga dapat berkontribusi secara signifikan terhadap koreksi ketidakharmonisan skeletal pada setiap pasien. ${ }^{3}$ Oleh sebab itu, waktu yang tepat untuk memulai perawatan tergantung pada periode pertumbuhan yang paling pesat. ${ }^{1,2}$

Penelitian epidemiologi menunjukkan prevalensi maloklusi kelas II sebanyak 20\% populasi di Amerika Serikat. Hasil serupa juga ditunjukkan oleh penelitian yang dilakukan terhadap populasi di Eropa. Prevalensi maloklusi kelas II pada populasi di Afrika adalah 1-10 \%, dan di Timur Tengah sejumlah $10-15 \%$. Penelitian yang dilakukan di Asia Timur dan Asia Tenggara juga menunjukkan prevalensi maloklusi kelas II yang sama dengan di Timur Tengah. ${ }^{4}$ Penelitian di Indonesia yang dilakukan oleh Wijayanti $\mathrm{dkk}^{5}$ pada sebuah sekolah dasar di Jakarta menunjukkan bahwa prevalensi maloklusi kelas II sebanyak $31.6 \%$.

\footnotetext{
*Program Pendidikan Dokter Gigi Spesialis IImu Kedokteran Gigi Anak, Fakultas Kedokteran Gigi Universitas Padjajaran, **Departemen Ilmu Kedokteran Gigi Anak, Fakultas Kedokteran Gigi Universitas Padjajaran Korespondensi : meirina.gartika@fkg.unpad.ac.id
} 
McNamara $^{6,7}$ melaporkan bahwa retrognati mandibula merupakan kondisi maloklusi kelas II skeletal yang lebih sering ditemukan. Beberapa metode diketahui dapat memajukan mandibula untuk memperbaiki maloklusi kelas II skeletal, diantaranya alat fungsional, alat ekstra oral, perawatan kamuflase, dan reposisi rahang melalui tindakan bedah. ${ }^{1,4}$ Alat fungsional twin block terdiri dari plat akrilik maksila dan mandibula dengan tanggul gigitan yang dapat memposisikan mandibula ke depan pada saat gerakan menutup mulut. ${ }^{4}$ Indikasi alat twin block adalah untuk memperbaiki maloklusi kelas II skeletal dengan karakteristik adanya retrognati mandibula. ${ }^{8-11}$

Alat fungsional lebih sering digunakan dalam perawatan defisiensi mandibula pada anak dalam masa pertumbuhan melalui stimulasi pertumbuhan mandibula. ${ }^{12-13}$ Alat fungsional mengarahkan pola dan arah pertumbuhan mandibula melalui gaya yang dihasilkan oleh kompleks neuromuskular. ${ }^{13,14}$

Puncak kecepatan pertumbuhan skeletal dapat dideteksi melalui beberapa metode penilaian. Penggunaan usia kronologis saja tidak cukup untuk menunjukkan level maturitas skeletal. ${ }^{1,2,15,16} \mathrm{Hal}$ tersebut disebabkan oleh variasi pertumbuhan individual. ${ }^{15}$ Usia fisiologis merupakan usia yang ditentukan oleh tingkat perkembangan fungsional dari berbagai sistem jaringan tubuh yang berbeda. Indikatorindikator fisiologis ini antara lain tinggi badan, maturasi skeletal telapak dan pergelangan tangan (hand wrist), perkembangan dan erupsi gigi, menstruasi, perubahan seksual sekunder seperti perkembangan payudara dan perubahan suara, serta cervical vertebral maturation. ${ }^{1,2,8} \quad$ Metode cervical vertebral maturation stage (CVMS) menunjukkan korelasi yang signifikan dengan pertumbuhan mandibula.3,8

Perawatan maloklusi dentoskeletal kelas
II divisi 1 disertai retrognati mandibula dengan alat twin block yang dilakukan pada pasien tumbuh kembang menunjukkan hasil yang baik dalam meningkatkan dimensi mandibula dan pengurangan overjet. ${ }^{14,17-20}$ Penelitian-penelitian lain menyatakan hal serupa, namun dengan menambahkan bahwa perawatan menunjukkan hasil yang baik jika dilakukan pada tahap awal gigi campuran atau pada tahap akhir gigi campuran. ${ }^{21}$ Penelitian yang dilakukan oleh Singh dan Clark ${ }^{22}$ meneliti efektivitas perawatan twin block berdasarkan waktu sebelum dan setelah pubertas.

\section{METODE PENELITIAN}

Penelitian ini adalah penelitian analitis retrospektif, dengan menggunakan data sekunder berupa radiograf sefalometri lateral pasien usia pertumbuhan dengan maloklusi dentoskeletal kelas II divisi 1 disertai retrognati mandibula sebelum dan sesudah perawatan dengan alat twin block di klinik Departemen IImu Kedokteran Gigi Anak Universitas Padjadjaran periode tahun 2010-2016. Pengambilan sampel dilakukan secara purposive sampling yang memenuhi kriteria inklusi dan eksklusi. Analisis data yang digunakan adalah uji t-berpasangan untuk membandingkan hasil pengukuran penapakan sefalogram lateral sebelum dan setelah perawatan dengan alat twin block serta untuk melihat tahap maturasi (CVMS) dengan perubahan paling signifikan.

\section{HASIL PENELITIAN}

Diperoleh sampel sebanyak 14 sefalogram lateral sebelum dan setelah perawatan dengan alat twin block yang memenuhi kriteria inklusi dan eksklusi. Distribusi jumlah sampel berdasarkan kelompok CVMS ditunjukkan 


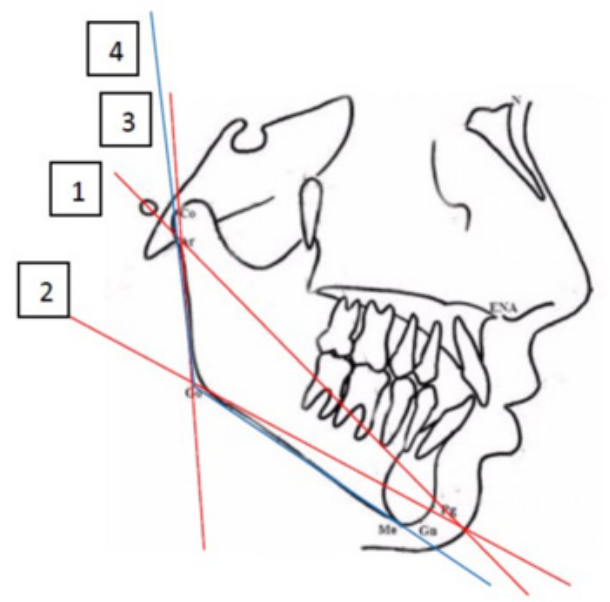

Gambar 1 Titik-titik sefalometri yang digunakan pada penelitian ${ }^{23}$ : 1.Panjang total mandibula (total mandibular length); 2.Panjang badan mandibula (mandibular body length); 3.Tinggi ramus (ramus height); 4.Sudut gonial (gonial angle)

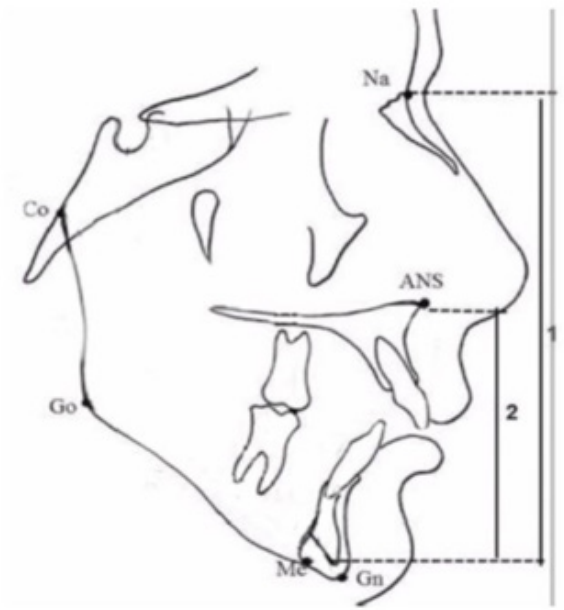

Gambar 2 Tinggi wajah anterior ${ }^{24}: 1$. Tinggi wajah anterior total; 2 . Tinggi wajah anterior bawah

Tabel 1. Jumlah Sampel Berdasarkan CVMS

\begin{tabular}{ccc}
\hline CVMS & n & $\%$ \\
\hline I & 0 & $0 \%$ \\
II & 3 & $21.43 \%$ \\
III & 6 & $42.86 \%$ \\
IV & 5 & $35.71 \%$ \\
V & 0 & $0 \%$ \\
VI & 0 & $0 \%$ \\
\hline Jumlah & 14 & $100 \%$ \\
\hline
\end{tabular}

Tabel 2 Hasil Uji t berpasangan Dimensi Mandibula Sebelum dan Sesudah Perawatan dengan Alat twin block

\begin{tabular}{ccccc}
\hline & \multicolumn{3}{c}{ Rata-rata (r) \pm SD } & \\
\cline { 2 - 4 } & Sebelum & Sesudah & Selisih & Nilai-p \\
\hline $\begin{array}{c}\text { Panjang total mandibula } \\
\text { (Ar-Pog) (mm) }\end{array}$ & $100.9 \pm 7.93$ & $104.2 \pm 9.36$ & $3.4 \pm 3.91$ & $\left.0.003398646^{*}\right)$ \\
$\begin{array}{c}\text { Panjang badan mandibula } \\
\text { (Go-Gn) (mm) }\end{array}$ & $72.1 \pm 5.29$ & $74.8 \pm 6.20$ & $2.6 \pm 1.45$ & $\left.5.99 \mathrm{E}-06^{*}\right)$ \\
$\begin{array}{c}\text { Tinggi ramus } \\
\text { (Co-Go) (mm) }\end{array}$ & $52.9 \pm 5.28$ & $55.3 \pm 6.57$ & $2.4 \pm 3.35$ & $\left.0.00880449^{*}\right)$ \\
$\begin{array}{c}\text { Sudut gonial } \\
\text { (Ar-Go-Me) (O) }\end{array}$ & $124.6 \pm 6.21$ & $126.6 \pm 5.67$ & $2.1 \pm 1.47$ & $\left.7.34556 \mathrm{E}-05^{*}\right)$ \\
\hline
\end{tabular}

Keterangan : Nilai p dihitung berdasarkan uji t

$\left.{ }^{*}\right)$ = bermakna dengan nilai $p<0.05$

pada Tabel 1.

Tabel 1 menunjukkan persentase jumlah sampel yang dikategorikan pada CVMS III paling besar yaitu $42.86 \%$. Jumlah sampel terbanyak selanjutnya adalah CVMS IV dengan persentase $35.71 \%$, dan terakhir
CVMS II sebanyak $21.43 \%$. Tidak ada satu sampel pun yang dikategorikan pada CVMS I, CVMS V, dan CVMS VI. Hasil uji t berpasangan pengukuran sefalometri dimensi mandibula sebelum dan sesudah perawatan dengan alat twin block dapat dilihat pada Tabel 2. 
Tabel 3 Hasil Uji Perbandingan Tinggi Wajah Anterior Sebelum dan Sesudah Perawatan dengan Alat twin block

\begin{tabular}{ccccc}
\hline & \multicolumn{3}{c}{ Rata-rata $(\hat{\mathrm{r}}) \pm \mathrm{SD}$} & \\
\cline { 2 - 4 } Variabel & Sebelum & Sesudah & Selisih & Nilai-p \\
\hline $\begin{array}{c}\text { Tinggi wajah anterior bawah } \\
\text { (ANS-Me) }(\mathrm{mm})\end{array}$ & $49.8 \pm 4.75$ & $52.2 \pm 4.35$ & $2.4 \pm 2.73$ & $\left.0.003008685^{*}\right)$ \\
$\begin{array}{c}\text { Tinggi wajah anterior total } \\
(\mathrm{N}-\mathrm{Me})(\mathrm{mm})\end{array}$ & $115.1 \pm 9.73$ & $118.5 \pm 10.35$ & $3.4 \pm 3.35$ & $\left.1.13 \mathrm{E}-03^{*}\right)$ \\
\hline
\end{tabular}

Keterangan : Nilai $p$ dihitung berdasarkan uji t

$\left.{ }^{*}\right)$ = bermakna dengan nilai $p<0.05$

Tabel 4. Hasil Uji Perbandingan Rata-Rata Perubahan Dimensi Mandibula Sebelum dan Sesudah Perawatan dengan Alat twin block Berdasarkan Kelompok CVMS

\begin{tabular}{|c|c|c|c|c|}
\hline CVMS & Variabel & $\begin{array}{c}\text { Rata-rata ( } \mathbf{r}) \\
\text { Sebelum }\end{array}$ & $\begin{array}{c}\text { Rata-rata ( } \mathbf{r}) \\
\text { Sesudah }\end{array}$ & $\begin{array}{c}\text { Rata-rata ( }(\hat{\mathbf{r}}) \\
\text { Beda }\end{array}$ \\
\hline \multirow[t]{4}{*}{ II } & Panjang total mandibula (Ar-Pog) (mm) & 96.8 & 98.0 & 1.2 \\
\hline & Panjang badan mandibula (Go-Gn) (mm) & 70.7 & 71.8 & 1.2 \\
\hline & Tinggi ramus (Co-Go) $(\mathrm{mm})$ & 50.3 & 52.5 & 2.2 \\
\hline & Sudut gonial (Ar-Go-Me) ( $\left.{ }^{\circ}\right)$ & 126.7 & 128.0 & 1.3 \\
\hline \multirow[t]{4}{*}{ III } & Panjang total mandibula (Ar-Pog) (mm) & 105.9 & 111.3 & 5.4 \\
\hline & Panjang badan mandibula (Go-Gn) (mm) & 75.8 & 79.8 & 3.9 \\
\hline & Tinggi ramus (Co-Go) $(\mathrm{mm})$ & 55.4 & 59.4 & 4.0 \\
\hline & Sudut gonial (Ar-Go-Me) ( $\left.{ }^{\circ}\right)$ & 122.2 & 125.3 & 3.1 \\
\hline \multirow[t]{4}{*}{ IV } & Panjang total mandibula (Ar-Pog) (mm) & 97.2 & 99.4 & 2.2 \\
\hline & Panjang badan mandibula (Go-Gn) (mm) & 68.6 & 70.6 & 2.0 \\
\hline & Tinggi ramus (Co-Go) $(\mathrm{mm})$ & 51.4 & 52.1 & 0.7 \\
\hline & Sudut gonial (Ar-Go-Me) ( $)$ & 126.2 & 127.5 & 1.3 \\
\hline
\end{tabular}

Tabel 5. Hasil Uji Perbandingan Rata-Rata Perubahan Tinggi Wajah Anterior Sebelum dan Sesudah Perawatan dengan Alat twin block Berdasarkan Kelompok CVMS

\begin{tabular}{|c|c|c|c|c|}
\hline CVMS & Variabel & $\begin{array}{l}\text { Rata-Rata ( } \mathbf{r}) \\
\text { Sebelum }\end{array}$ & 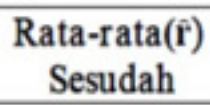 & $\begin{array}{c}\text { Rata-rata ( } \mathbf{r}) \\
\text { Beda }\end{array}$ \\
\hline \multirow[t]{2}{*}{ II } & $\begin{array}{l}\text { Tinggi wajah anterior bawah } \\
\text { (ANS-Me) (mm) }\end{array}$ & 47.0 & 48.5 & 1.5 \\
\hline & $(\mathrm{N}-\mathrm{Me})(\mathrm{mm})$ & 109.2 & 111.0 & 1.8 \\
\hline \multirow[t]{2}{*}{ III } & $\begin{array}{l}\text { Tinggi wajah anterior bawah } \\
\text { (ANS-Me) (mm) } \\
\text { Tinggi wajah anterior total }\end{array}$ & 50.3 & 54.0 & 3.7 \\
\hline & $(\mathrm{N}-\mathrm{Me})(\mathrm{mm})$ & 117.2 & 122.2 & 5.0 \\
\hline \multirow[t]{2}{*}{ IV } & $\begin{array}{l}\text { Tinggi wajah anterior bawah } \\
\text { (ANS-Me) (mm) }\end{array}$ & 50.8 & 52.2 & 1.4 \\
\hline & $(\mathrm{N}-\mathrm{Me})(\mathrm{mm})$ & 116.2 & 118.6 & 2.4 \\
\hline
\end{tabular}


Tabel 2 memperlihatkan perubahan pada variabel dimensi mandibula yang signifikan secara statistik. Terlihat nilai ratarata sesudah perawatan lebih besar dari sebelum perawatan. Hal ini berarti alat twin block menghasilkan perubahan pada dimensi mandibula. Perubahan paling besar terlihat pada panjang total mandibula (Ar-Pog) ratarata bertambah sebesar $3.4 \mathrm{~mm}(\mathrm{SD} \pm 3.91)$, dan paling kecil terlihat pada sudut gonial (ArGo-Me) rata-rata bertambah sebesar $2.1^{\circ}$ (SD \pm 1.47 ). Data hasil penelitian uji perbandingan pengukuran sefalometri tinggi wajah anterior sebelum dan sesudah perawatan dengan alat twin block dapat dilihat pada Tabel 3 .

Tabel 3 memperlihatkan perubahan pada variabel tinggi wajah anterior yang signifikan secara statistik. Terlihat nilai rata-rata sesudah perawatan lebih besar dari sebelum perawatan. Hal ini berarti alat twin block menghasilkan perubahan pada tinggi wajah anterior. Dua variabel yang diteliti menunjukkan perubahan, yaitu tinggi wajah anterior bawah (ANS-Me) rata-rata bertambah sebesar $2.4 \mathrm{~mm}$ (SD \pm 2.73), dan tinggi wajah anterior total (N-Me) rata-rata bertambah sebesar $3.4 \mathrm{~mm}$ (SD \pm 3.35). Data hasil penelitian uji perbandingan rata-rata perubahan dimensi mandibula sebelum dan sesudah perawatan dengan alat twin block berdasarkan kelompok CVMS dapat dilihat pada Tabel 4.

Tabel 4 menunjukkan bahwa kelompok CVMS III menunjukkan rata-rata beda yang paling besar untuk semua variabel dimensi mandibula. Hal ini berarti alat twin block menghasilkan perubahan paling signifikan pada CVMS III. Rata-rata beda paling besar selanjutnya adalah kelompok CVMS IV, dan yang terakhir adalah CVMS II. Data hasil penelitilan uji perbandingan rata-rata perubahan tinggi wajah anterior sebelum dan sesudah perawatan dengan alat twin block berdasarkan kelompok CVMS dapat dilihat pada Tabel 5.

Tabel 5 menunjukkan bahwa kelompok CVMS III menunjukkan rata-rata beda yang paling besar untuk semua variabel tinggi wajah anterior. Hal ini berarti alat twin block menghasilkan perubahan paling signifikan pada CVMS III. Rata-rata beda paling besar selanjutnya adalah kelompok CVMS IV, dan yang terakhir adalah CVMS II.

\section{DISKUSI}

Maloklusi kelas II divisi I disertai retrognati mandibula merupakan kondisi kelas II yang paling sering ditemukan. 6,7 Tujuan utama dari alat twin block adalah untuk merangsang pertumbuhan mandibula melalui stimulasi pertumbuhan pada kartilago kondilus dan membatasi pertumbuhan maksila secara fungsional.

Distribusi sampel dalam penelitian ini paling besar pada CVMS III. Hal ini dikarenakan perawatan alat fungsional diindikasikan pada pasien yang sedang dalam masa pubertas ketika mandibula sedang bertumbuh dengan pesat. Kondisi ini sejalan dengan penelitian yang dilakukan oleh Sander ${ }^{25}$ yang menyatakan bahwa pertumbuhan tulang fasial maksimum akibat perawatan alat fungsional terjadi pada interval CVMS III dan IV. Penelitian yang dilakukan oleh Franchi $\mathrm{dkk}^{26}$ juga menyatakan hal yang serupa, yaitu CVMS III dan CVMS IV merupakan tahap terjadinya puncak pertumbuhan pubertal. Hal inilah yang menyebabkan seluruh sampel berada pada tahap maturasi skeletal usia pertumbuhan.

Analisis penggunaan alat twin block dapat ditinjau dari perubahan dimensi mandibula dan tinggi wajah anterior. Keempat belas sampel yang ditelitimenunjukkan perubahan yang signifikan pada seluruh variabel 
dari dimensi mandibula dan tinggi wajah anterior. Variabel ukuran linear panjang total mandibula mengalami peningkatan setelah perawatan. Hal ini terjadi karena alat twin block berfungsi untuk menstimulasi pertumbuhan mandibula melalui pertumbuhan kartilago kondilus, sehingga pertumbuhan endokondral akan terjadi lebih pesat. $8,21,22$

Hal yang sama juga terjadi pada variabel ukuran linear panjang badan mandibula dan tinggi ramus. Perubahan linear mandibula paling besar terlihat pada variabel panjang total mandibula. Hal ini disebabkan adanya sinergi dari peningkatan panjang badan mandibula dan tinggi ramus secara simultan. ${ }^{8}$

Hasil penelitian ini sejalan dengan penelitian Al-Anezi ${ }^{17}$, Singh dkk ${ }^{21}$, dan Fareen $\mathrm{dkk}^{20}$ yang menyatakan bahwa alat twin block akan meningkatkan panjang mandibula secara keseluruhan sehingga sudut ANB akan berkurang. Bacetti $\mathrm{dkk}^{8}$ dalam penelitiannya juga menyatakan bahwa perubahan skeletal yang paling tampak setelah perawatan twin block adalah perubahan skeletal pada mandibula.

Variabel ukuran angular sudut gonial mengalami peningkatan setelah perawatan. Hal ini disebabkan oleh peningkatan tinggi ramus dan panjang badan mandibula, diiringi dengan pertumbuhan mandibula ke arah depan dan bawah menyebabkan bertambahnya sudut gonial. Peningkatan sudut gonial juga merupakan akibat dari pertumbuhan kondilus ke posterior dan superior. ${ }^{17}$ Alat twin block akan menambah ukuran mandibula jika dibandingkan dengan pertumbuhan mandibula secara normal. ${ }^{27}$ Selain itu, peningkatan tinggi vertikal wajah juga akan meningkatkan besar sudut gonial. ${ }^{28}$

Variabel tinggi wajah anterior juga dinilai untuk menganalisis penggunaan alat twin block terhadap perawatan maloklusi kelas II divisi 1 disertai dengan retrognati mandibula, antara lain melalui penilaian variabel ukuran tinggi wajah anterior bawah, serta variabel ukuran tinggi wajah anterior total. Kedua variabel ini mengalami perubahan yang signifikan secara statistik.

Ukuran tinggi wajah anterior bawah dan tinggi wajah anterior total mengalami peningkatan setelah perawatan. Peningkatan tinggi vertikal wajah ini sejalan dengan penelitian Al-Anezi ${ }^{17}$, Singh dkk ${ }^{21}$, dan Fareen $\mathrm{dkk}^{20}$ yang menyatakan bahwa alat twin block akan menghasilkan peningkatan tinggi wajah. Perubahan tinggi wajah anterior ini dihasilkan dari rotasi searah jarum jam dari pertumbuhan mandibula. ${ }^{29}$ Peningkatan sudut gonial dan peningkatan tinggi ramus juga akan meningkatkan tinggi wajah anterior. ${ }^{28}$

Hasil pengujian rata-rata beda sebelum dan sesudah perawatan dengan alat twin block menunjukkan hasil yang signifikan secara statistik dengan rata-rata beda paling besar terjadi pada kelompok CVMS III. Rata-rata beda paling besar terlihat pada CVMS III di semua variabel dimensi mandibula dan tinggi wajah anterior. Hal ini sesuai dengan penelitian oleh Baccetti $\mathrm{dkk}^{3}$ yang menyatakan bahwa CVMS III merupakan tahap yang paling ideal untuk memulai perawatan dengan alat fungsional ortopedi. Puncak pertumbuhan mandibula dan tinggi badan terjadi pada interval CVMS III dan CVMS IV. ${ }^{26,30}$

Perawatan maloklusi dentoskeletal kelas II menunjukkan hasil paling baik jika dilakukan pada saat atau sesaat setelah growth spurt pubertal. ${ }^{8}$ Hal tersebut disebabkan adanya interaksi yang sinergis antara perubahan fungsi yang dihasilkan oleh alat fungsional dan hormon pertumbuhan yang menunjukkan kuantitas paling besar di usia pubertas, yaitu pada tahap akhir periode gigi campuran atau pada tahap awal periode gigi permanen. ${ }^{7}$ 
Efektivitas perawatan terbesar dapat diperoleh pada puncak pertumbuhan pubertas (growth spurt) yaitu ketika tulang fasial sedang bertumbuh dengan pesat.

Metode CVMS terbukti menunjukkan korelasi yang signifikan dengan pertumbuhan mandibula. ${ }^{3,8}$ Rata-rata perubahan paling kecil pada penelitian ini terjadi di kelompok CVMS II. CVMS II merupakan prepeak stage, sehingga perawatan ortopedi dapat ditangguhkan minimal 1 tahun kemudian. Hal serupa dinyatakan pada penelitian yang dilakukan oleh Sander ${ }^{25}$ terhadap 132 pasien yang dirawat dengan alat fungsional selain twin block yaitu Bionator, Fränkel, dan MARA, bahwa pertumbuhan tulang fasial maksimum akibat perawatan terjadi pada interval CVMS III dan IV.

\section{KESIMPULAN}

Berdasarkan hasil analisis dapat diambil kesimpulan bahwa penggunaan alat twin block terhadap perawatan maloklusi dentoskeletal kelas II divisi 1 disertai retrognati mandibula meningkatkan dimensi mandibula dan tinggi wajah anterior. Cervical vertebral maturation stage III (CVMS III) adalah waktu yang paling efektif untuk memulai perawatan dengan alat twin block.

\section{DAFTAR PUSTAKA}

1. Šidlauskas A, Žilinskaitè L, Švalkauskienè V. Mandibular Pubertal Growth Spurt Prediction. Part One: Method Based on the Hand-Wrist Radiographs. Baltic Dental and Maxillofacial Journal. 2005;7:16-20.

2. Valizadeh S, Eil N, Ehsani S, Bakhshandeh $\mathrm{H}$. Correlation Between Dental and Cervical Vertebral Maturation in Iranian Female. Iranian Journal of Radiology. 2013;10(1):1-7.

3. Baccetti T, Franchi L, McNamara JA. An Improved Version of the Cervical Vertebral Maturation (CVM) Method for the Assessment of Mandibular Growth. Angle Orthodontist. 2002;72(4):159-70.
4. Saptarini R, Gartika M, Runkat J. Penggunaan Twin Blok pada Perawatan Maloklusi kelas II Angle Anak-anak. Indonesian Journal of Dentistry. 2005;12(2):50-4.

5. Wijayanti P, Krisnawati, Ismah N. Gambaran maloklusi dan kebutuhan perawatan ortodonti pada anak usia 9-11 tahun (Studi pendahuluan di SD At-Taufiq, Cempaka Putih, Jakarta. Jurnal PDGI. 2014;63(1):25-9.

6. McNamara J, Bookstein F, Shaughnessys T. Skeletal and dental changes following functional regulator therapy on Class II patient. Am J Orthod Dentofacial Orthop. 1985;88:91-110.

7. McNamara JA, Brudon WL. Orthodontic and Orthopedic Treatment in the Mixed Dentition. United States of America: Needham Press; 1993.86-9.

8. Baccetti T, Franchi L, Toth LR, McNamara JA. Treatment timing for Twin-block therapy. Am J Orthod Dentofacial Orthop. 2000;118 159-70.

9. Clark WJ. Twin Block Functional Therapy Applications in Dentofacial Orthopedics. 3rd edition. New Delhi: Jaypee Brothers Medical Publishers (P) Ltd; 2015: 6-18.

10. Ireland AJ, McDonald F. The Orthodontic Patient : Treatment and Biomechanics.New York: Oxford University Press Inc; 2003: 89-109.

11. Jena AK. Effectiveness of twin block and mandibular protraction appliance-IV in the improvement of pharyngeal airway passage dimension in class II malocclusion subjects with a retrognatic mandible. Angle $\mathrm{J}$ orthodontics. 2013;83:728-43.

12. Graber T, Rakosi T, ADento-facial Orthopedics with Functional Appliances. St Louis: Mosby; 1997.

13. Jamilian A, Rahman S. Treatment effect of the R-appliance and twin block in class II division 1 malocclusion. European Journal of Orthodontics. 2011;33:354-8.

14. Mathew T. Management of skeletal class II malocclusion with twin block and fixed appliance for 12- year-old. Journal of pharmaceutical and biomedical sciences 2013;28:650-6.

15. Al-Hadlaq A, Al-Qarni M, Al-Kahtani A, Al-Obaid A. Comparative Study Between Hand-Wrist Method And Cervical Vertebral Maturation Method For Evaluation Of Skeletal Maturity In Saudi Boys. Pakistan Oral \& Dental Journal 2002;27(2):27-32.

16. Alhadlaq AM, Al-Shayea El. New method for evaluation of cervical vertebral maturation based on angular measurements. Saudi Med J. 2012;33(4):388-94.

17. Al-Anezi SA. Class II malocclusion treatment using combined Twin Block and fixed orthodontic appliances - A case report. The Saudi Dental Journal 2011;23:43-51.

18. O'Brien K, Wright J, Conboy F. Early treatment with the twin block appliance is effective in reducing overjet and severity of malocclusion. 
Am J Orthod Dentofacial Orthop. 2003;124:23443.

19. Patel B, Baswaraj H, Tandur AP, Agrawal C, Chokshi $\mathrm{H}$, Mahida K. Class II correction using twin block appliance: A case report. International Journal of Contemporary Dentistry 2015;6:4-6.

20. Fareen N, Alam M, Khamis M. The efficcacy of twin block as functional appliance : An overview. Int J Pharm Bio Sci. 2015;6(3):1066-75.

21. Singh $M$, Vashisth $P$, Chaundhary $S$, Sinha $A$. Early treatment outcomes of class II malocclusion with twin block facial profile and cephalometric change. Journal of Oral Biology and Craniofacial Researc. 2012;2(1):61-6.

22. Singh G, Clark W. Localization of mandibular changes in patients with class II division 1 malocclusion treated with twin block appliances : Finite element scaling analysis. J Orthod Dentofacial Orthop. 2001;119:419-25.

23. Baccetti $T$, Franchi L, McNamara J. The cervical vertebral maturation (CVM) method for assessment of optimal treatment timing in dentofacial orthopedics. 2005:1-5.

24. Šidlauskas A. Clinical Effectiveness of the Twin Block Appliance in the Treatment of Class II Division 1 Malocclusion. Baltic Dental and Maxillofacial Journal. 2005;7:7-10.

25. Sander D. Use of CVM stages in assessment of young orthodontic patients to estimate growth potential. Tennessee: The University of Tennessee; 2009:87-8.
26. Franchi L, Baccetti T, McNAmara J. Mandibular growth as related to cervical vertebral maturation and body height Am J Orthod Dentofacial Orthop. 2000;118:335-40.

27. Diaz PA, Ruz GA, Palomino HM. Discovering craniofacial patterns using multivariate cephalometric data for treatment decision making in orthodontics. International Journal of Morphology. 2013;31(3):1109-15.

28. Baysal A, Uysal T. Dentoskeletal effects of twin block and Herbst appliances in patients with class II division 1 mandibular retrognathy. European Journal of Orthodontics. 2013:10-6.

29. Wang MF, Otsuka T, Sato S. Vertical facial height and its correlationn with facial width and depth. International Journal of Stomatology and Occlusion Medicine. 2013;6:120-9.

30. Quintao C, Helena I, Brunharo V, Menezes R, Almeida M. Soft tissue facial profile changes following functional appliance therapy. European Journal of Orthodontics. 2006;28(1):35-41. 